\title{
Research on problem solving skills of orienteering athletes in terms of some variables
}

\author{
Başak Eroğlu ${ }^{1 \mathrm{a}}$, and Arif Kaan Eroğlu ${ }^{2}$ \\ ${ }^{1}$ Namık Kemal University College of Physical Education and Sports, 59000, Tekirdağ, Turkey \\ ${ }^{2}$ Yüzüncü Y1l University College of Physical Education and Sports, 65100, Van, Turkey
}

\begin{abstract}
The aim of this study is to examine the problem solving skills of orienteering athletes in terms of different variables. 157 male and 43 female orienteering athletes, making a total of 200 athletes that joined the 3rd Level of Turkey Championship in 2015 have participated in this study which is in a survey model. The data collection tools were the Problem Solving Inventory and Personal Information Form that were formed by Heppner \& Peterson (1982) and adapted into Turkish by Şahin, Şahin \& Heppner (1993). In the data analysis, descriptive statics, anova, $t$ test and Tukey test have been utilized. In the line with the findings, it has been determined that the difference between the total mean values $(85.55+20.45)$ that the orienteering athletes got from the problem solving inventory and their age, marital status, sports age, the years of practice in orienteering sports, and the status of being national player is significant $(\mathrm{p}<0.05)$. It has been found that male orienteering athletes perform higher evaluating approach compared to the female athletes, and that as the age levels increase, the problem solving skill is affected more positively. Furthermore, it has been determined that the perceptions of the participants that have more experience and sports age in orienteering sports and that do orienteering sports at a national level are more positive in the matter of problem solving skills.
\end{abstract}

\section{Introduction}

The root of the word problem comes from a Greek word "problema" and is lexicalised from "proballein" word in Greek which means "to make an effort" [22]. Adair (2007) described the problem as "a situation preventing the individual" [2]. Problem is the difference between present situation of the individual and the situation in which he/she would like to be [21].

When there are no certain solutions, cognitive process aimed at achieving the target is called solving a problem [19]. Problem solving which was used by Heppner \& Krauskopf

${ }^{a}$ Corresponding author: beroglu@yyu.edu.tr 
(1987) being in synonymous with overcoming concept [13], makes development of the individual by discovering his/her talents and meeting his/her needs easier [9]. Problem solving ability helps effective adjustment of the individual and the group to the environment where they live in [28].

According to Morgan (1981), problem solving describes a process starting from perceiving the problem by the individual to finding a solution to it [20]. Problem solving is constituted of stages such as identification of problem, formation of suitable choices, finding the best solution among choices, etc. [2].

Orienteering is a branch of sports which is a combination of map reading and cross country running. The competitors determine their own routes in different areas by using topographic map and compass [7]. In this branch of sports, the abilities of independently thinking and tiding over under stress and pressure are developed as well as physical properties. While sportsmen learn how to focus on truth by taking lessons from mistakes, the abilities of thinking logically, analysing and solving problems independently are also developed [6].

\subsection{The Aim of the Research}

The aim of this study is to examine the problem solving skills of orienteering athletes in terms of different variables.

\subsection{The Problem of the Research}

It was aimed to find out which variables effect the problem solving skills of orienteering athletes.

\section{Method}

157 male and 43 female orienteering athletes, making a total of 200 athletes that joined the 3rd Level of Turkey Championship in 2015 have participated in this study which is in a survey model.

The data collection tools were the Problem Solving Inventory and Personal Information Form that were formed by Heppner \& Peterson (1982) and adapted into Turkish by Şahin, Şahin \& Heppner (1993) [12,29]. Problem Solving Inventory constituted of 35 items and six sub-dimensions (impatient, deliberative, avoiding, evaluating, self-confident and planned approach). Grades varying between 1 (I always behave like this) and 6 (I never behave like this) were given to the answers in the inventory. The grading was performed with 32 items except 9th, 22nd and 29th items. The items numbered with 1, 2, 3, 4, 11,13, $14,15,17,21,25,26,30$ and 34 were graded inversely. The lowest and highest grades that can be taken at the end of the inventory were 32 and 192, respectively. The higher grades taken from the inventory indicate that the individual perceived him/herself as insufficient about his/her abilities of problem solving. As the grades taken from sub-dimensions (thinking approach, self-confident approach, evaluating approach and planned approach) which can be considered as positive problem solving approach styles are decreased, it is thought that they are used more. As the grades taken from sub-dimensions (impatient and avoiding approaches) which can be considered as negative problem solving approach styles are decreased, it is thought that they are used less. Internal consistency coefficient of the inventory was .88 and reliability coefficient was calculated as $r=.81$.

In the data analysis, descriptive statics, Anova, $t$ test and Tukey test have been utilized. 


\section{Findings}

The average grades and standard deviations related with problem solving sub-dimensions of orienteering athletes were evaluated and it was found that impatient approach was $\bar{X}=29.76 \pm 7.47$, thinking approach was $\bar{X}==11.91 \pm 4.4$, avoiding approach was $\bar{X}=10.95 \pm 4.87$, evaluating approach was $\bar{X}=7.31 \pm 2.78$, self-confident approach was $\overline{\mathrm{X}}=16.43 \pm 5.41$ and planned approach was $\overline{\mathrm{X}}=9.17 \pm 3.65$. The average value of total grades taken from problem solving inventory of orienteering athletes was determined as $85.55 \pm$ 20.45 .

According to Table 1, a significant difference between genders of athletes and evaluating approach sub-dimension was found in favour of male athletes $(7.04 \pm 2.65)$ when compared to female athletes $(8.3 \pm 3.03)(\mathrm{p}<0.05)$.

Table 1. Problem solving abilities of orienteering athletes in terms of gender

\begin{tabular}{lcccc}
\hline Problem Solving & $\mathbf{N}$ & Gender & $\overline{\mathbf{X}} \pm$ SD & P \\
\hline \multirow{2}{*}{ Impatient } & 157 & Men & $29.75 \pm 7.3$ & 0.98 \\
& 43 & Women & $29.79 \pm 8.13$ & \\
Thinking & 157 & Men & $11.68 \pm 4.42$ & 0.16 \\
& 43 & Women & $12.74 \pm 4.28$ & 0.86 \\
Avoiding & 157 & Men & $10.92 \pm 5.22$ & \\
& 43 & Women & $11.06 \pm 3.33$ & \\
Evaluating & 157 & Men & $7.04 \pm 2.65$ & $0.00^{*}$ \\
Self-confident & 43 & Women & $8.3 \pm 3.03$ & \multirow{2}{*}{0.16} \\
& 157 & Men & $16.15 \pm 5.44$ & 0.31 \\
Planned & 43 & Women & $17.44 \pm 5.21$ & \\
& 157 & Men & $9.03 \pm 3.81$ & 0.21 \\
Total & 43 & Women & $9.67 \pm 2.95$ & \\
\hline
\end{tabular}

$\left({ }^{*} \mathrm{p}<0.05\right)$

As seen in Table 2, the grades of married orienteering athletes taken from problem solving inventory was found significantly different from those of single athletes except impatient approach sub-dimension $(\mathrm{p}<0.05)$. It was determined that married orienteering athletes used positive problem solving approach styles (thinking, self-confident, evaluating and planned) more than single athletes and moreover single athletes preferred avoiding approach sub-dimension more than married athletes. The total problem solving ability perception of married athletes was found more positive when compared to single athletes.

Table 2. Problem solving abilities of orienteering athletes in terms of their marital status

\begin{tabular}{lcccc}
\hline Problem Solving & $\mathbf{N}$ & Marital status & $\overline{\mathbf{X}} \pm$ SD & p \\
\hline \multirow{2}{*}{ Impatient } & 27 & Married & $27.44 \pm 7.74$ & 0.08 \\
& 173 & Single & $30.12 \pm 7.38$ & \\
Thinking & 27 & Married & $9.29 \pm 3.73$ & $0.00^{*}$ \\
& 173 & Single & $12.32 \pm 4.36$ & \\
Avoiding & 27 & Married & $8.81 \pm 4.51$ & $0.01^{*}$ \\
& 173 & Single & $11.28 \pm 4.85$ & \\
Evaluating & 27 & Married & $6.14 \pm 2.58$ & $0.01^{*}$ \\
& 173 & Single & $7.49 \pm 2.77$ & \\
Self-confident & 27 & Married & $13.22 \pm 4.42$ & $0.00^{*}$ \\
& 173 & Single & $16.93 \pm 5.39$ & \\
Planned & 27 & Married & $7.48 \pm 2.73$ & $0.00^{*}$ \\
& 173 & Single & $9.43 \pm 3.71$ & \\
Total & 27 & Married & $72.4 \pm 18.78$ & $0.00^{*}$ \\
\hline
\end{tabular}


$(* \mathrm{p}<0.05)$

A significant difference was found between ages of athletes together with impatient, avoiding and thinking approach sub-dimensions and total problem solving grades $(p<0.05)$. It was observed that as the age of athletes increased, they used negative approach styles less and preferred thinking approach sub-dimension more (Table 3).

Table 3. Problem solving abilities of orienteering athletes in terms of age groups

\begin{tabular}{|c|c|c|c|c|}
\hline Problem Solving & $\mathbf{N}$ & Age & $\overline{\mathbf{X}} \pm$ SD & p \\
\hline \multirow{6}{*}{ Impatient } & 42 & $15-17$ & $31.97 \pm 7.24$ & \multirow{6}{*}{$0.003^{*}$} \\
\hline & 86 & $18-20$ & $30.29 \pm 7.24$ & \\
\hline & 30 & $21-23$ & $30.93 \pm 8.81$ & \\
\hline & 13 & $24-26$ & $25.23 \pm 4.78$ & \\
\hline & 9 & $27-29$ & $26.44 \pm 5.36$ & \\
\hline & 20 & up to 30 & $25.55 \pm 6.3$ & \\
\hline \multirow{6}{*}{ Thinking } & 42 & $15-17$ & $12.92 \pm 4.54$ & \multirow{6}{*}{$0.00 *$} \\
\hline & 86 & $18-20$ & $12.79 \pm 4.49$ & \\
\hline & 30 & $21-23$ & $11.66 \pm 4.02$ & \\
\hline & 13 & $24-26$ & $9.76 \pm 3.32$ & \\
\hline & 9 & $27-29$ & $8.33 \pm 2.5$ & \\
\hline & 20 & up to 30 & $9.4 \pm 3.48$ & \\
\hline \multirow{6}{*}{ Avoiding } & 42 & $15-17$ & $12.19 \pm 4.7$ & \multirow{6}{*}{$0.00^{*}$} \\
\hline & 86 & $18-20$ & $12.22 \pm 5.28$ & \\
\hline & 30 & $21-23$ & $10.06 \pm 3.59$ & \\
\hline & 13 & $24-26$ & $7.84 \pm 2.26$ & \\
\hline & 9 & $27-29$ & $7.22 \pm 2.77$ & \\
\hline & 20 & up to 30 & $7.95 \pm 3.88$ & \\
\hline \multirow{6}{*}{ Evaluating } & 42 & $15-17$ & $7.85 \pm 3.04$ & \multirow{6}{*}{0.25} \\
\hline & 86 & $18-20$ & $7.51 \pm 2.75$ & \\
\hline & 30 & $21-23$ & $7.26 \pm 3.26$ & \\
\hline & 13 & $24-26$ & $6.53 \pm 1.94$ & \\
\hline & 9 & $27-29$ & $6.55 \pm 2.35$ & \\
\hline & 20 & up to 30 & $6.25 \pm 1.88$ & \\
\hline \multirow{6}{*}{ Self-confident } & 42 & $15-17$ & $17.9 \pm 4.84$ & \multirow{6}{*}{0.13} \\
\hline & 86 & $18-20$ & $16.67 \pm 5.5$ & \\
\hline & 30 & $21-23$ & $16.23 \pm 5.59$ & \\
\hline & 13 & $24-26$ & $14.76 \pm 4.98$ & \\
\hline & 9 & $27-29$ & $14 \pm 5.74$ & \\
\hline & 20 & up to 30 & $14.75 \pm 5.49$ & \\
\hline \multirow{6}{*}{ Planned } & 42 & $15-17$ & $9.85 \pm 4.95$ & \multirow{6}{*}{0.16} \\
\hline & 86 & $18-20$ & $9.59 \pm 3.13$ & \\
\hline & 30 & $21-23$ & $8.73 \pm 3.34$ & \\
\hline & 13 & $24-26$ & $7.76 \pm 2.61$ & \\
\hline & 9 & $27-29$ & $7.88 \pm 2.31$ & \\
\hline & 20 & up to 30 & $8.1 \pm 3.69$ & \\
\hline \multirow{6}{*}{ Total } & 42 & $15-17$ & $92.71 \pm 17.19$ & \multirow{6}{*}{$0.00 *$} \\
\hline & 86 & $18-20$ & $89.08 \pm 20.31$ & \\
\hline & 30 & $21-23$ & $84.9 \pm 20.81$ & \\
\hline & 13 & $24-26$ & $71.92 \pm 14.94$ & \\
\hline & 9 & $27-29$ & $70.44 \pm 17.38$ & \\
\hline & 20 & up to 30 & $72 \pm 19.18$ & \\
\hline
\end{tabular}

$\left({ }^{*} \mathrm{p}<0.05\right)$

When the years of experience and the grades taken from problem solving inventory of athletes in orienteering sports were investigated, a significant difference was found except evaluating and planned approach sub-dimensions $(\mathrm{p}<0.05)$. As the experience of athletes in 
the branch of sports is enhanced, their perceptions of problem solving ability become more positive (Table 4.)

Table 4. Problem solving abilities of orienteering athletes in terms of their experience in sports

\begin{tabular}{|c|c|c|c|c|}
\hline Problem Solving & $\mathbf{N}$ & Sport ages in orienteering & $\overline{\mathbf{X}} \pm \mathbf{S D}$ & p \\
\hline \multirow{3}{*}{ Impatient } & 131 & $1-3$ ages & $30.84 \pm 7.69$ & \multirow{3}{*}{$0.01^{*}$} \\
\hline & 35 & 4-6 ages & $27.57 \pm 7.36$ & \\
\hline & 34 & up to 7 & $27.85 \pm 5.82$ & \\
\hline \multirow{3}{*}{ Thinking } & 131 & 1-3 ages & $12.83 \pm 4.56$ & \multirow{3}{*}{$0.00^{*}$} \\
\hline & 35 & 4-6 ages & $10.8 \pm 3.6$ & \\
\hline & 34 & up to 7 & $9.52 \pm 3.28$ & \\
\hline \multirow{3}{*}{ Avoiding } & 131 & 1-3 ages & $11.77 \pm 4.73$ & \multirow{3}{*}{$0.00^{*}$} \\
\hline & 35 & 4-6 ages & $9.4 \pm 4.05$ & \\
\hline & 34 & up to 7 & $9.38 \pm 5.46$ & \\
\hline \multirow{3}{*}{ Evaluating } & 131 & 1-3 ages & $7.62 \pm 2.92$ & \multirow{3}{*}{0.06} \\
\hline & 35 & 4-6 ages & $7.02 \pm 2.47$ & \\
\hline & 34 & up to 7 & $6.41 \pm 2.33$ & \\
\hline \multirow{3}{*}{ Self-confident } & 131 & 1-3 ages & $17.25 \pm 5.5$ & \multirow{3}{*}{$0.01 *$} \\
\hline & 35 & 4-6 ages & $14.94 \pm 3.94$ & \\
\hline & 34 & up to 7 & $14.76 \pm 5.78$ & \\
\hline \multirow{3}{*}{ Planned } & 131 & 1-3 ages & $9.53 \pm 3.82$ & \multirow{3}{*}{0.06} \\
\hline & 35 & 4-6 ages & $9.05 \pm 3.67$ & \\
\hline & 34 & up to 7 & $7.91 \pm 2.58$ & \\
\hline \multirow{3}{*}{ Total } & 131 & 1-3 ages & $89.87 \pm 20.05$ & \multirow{3}{*}{$0.00^{*}$} \\
\hline & 35 & 4-6 ages & $78.8 \pm 17 \mathrm{i} 78$ & \\
\hline & 34 & up to 7 & $75.85 \pm 19.8$ & \\
\hline
\end{tabular}

$\left({ }^{*} \mathrm{p}<0.05\right)$

As seen in Table 5, the grades of national athletes taken from problem solving inventory were found significantly different from non-national athletes except impatient, selfconfident and planned approach sub-dimensions $(p<0.05)$. It was determined that national athletes used thinking and evaluating approach sub-dimensions more than non-national athletes and moreover, non-national athletes preferred avoiding approach sub-dimension more than national athletes. Total problem solving ability perception of national athletes was found more positive when it was compared with that of non-national athletes.

Table 5. Problem solving abilities of orienteering athletes in terms of being national

\begin{tabular}{ccccc}
\hline Problem Solving & $\mathbf{N}$ & Status of being national player & $\overline{\mathbf{X}} \pm$ SD & $\mathbf{p}$ \\
\hline Impatient & 40 & National player & $28.2 \pm 6.76$ & 0.13 \\
& 160 & No national player & $30.15 \pm 7.6$ & \\
Thinking & 40 & National player & $10.07 \pm 3.76$ & $0.00^{*}$ \\
& 160 & No national player & $12.37 \pm 4.44$ & \\
Avoiding & 40 & National player & $9.2 \pm 4.26$ & $0.01^{*}$ \\
& 160 & No national player & $11.39 \pm 4.92$ & \\
Evaluating & 40 & National player & $6.42 \pm 2.21$ & $0.02 *$ \\
& 160 & No national player & $7.53 \pm 2.87$ & \\
Self-confident & 40 & National player & $14.85 \pm 5.54$ & 0.03 \\
& 160 & No national player & $16.82 \pm 5.32$ & \\
Planned & 40 & National player & $8.17 \pm 2.75$ & 0.05 \\
& 160 & No national player & $9.42 \pm 3.81$ & \\
Total & 40 & National player & $76.92 \pm 18.46$ & $0.00 *$ \\
& 160 & No national player & $87.93 \pm 20.28$ & \\
\hline
\end{tabular}

$\left({ }^{*} \mathrm{p}<0.05\right)$ 


\section{Results and Discussion}

When the findings obtained from the research were evaluated, it was determined that average of total grades that the athletes got from problem solving inventory was $\bar{X}=85.55$. It can be concluded that orienteering athletes well assessed problem solving stages and found a solution and came through after determination of the best choice among existing solutions. By orienteering sports' nature, the athletes were successful when they found the most suitabel solution in an unknown situation. While finding a solution, their own abilities, physical properties and problem solving abilities were effective. The grades of orienteering athletes taken from sub-dimensions as well as averages of their total problem solving grades were similar with those of previous studies in literature. In the study of Kuru $\&$ Karabulut (2009), the average of grades taken from rhythm education and dance lecture by students was found as $(\overline{\mathrm{X}}=83.81)$ [18]. Pehlivan \& Öksüzoğlu (2006) indicated that average of problem solving grades of football players and dancers were $(\overline{\mathrm{X}}=84.53)$ and $(\bar{X}=82.95)$ [26], respectively. It was determined by Çağlayan et al. (2008) that the students doing exercises took similar grades $(\overline{\mathrm{X}}=90.68)$ [5]. In the studies of Karabulut \& Pulur (2011) on students doing active exercises, Acar (2013) on children doing football exercises, Akandere et al. (2010) on university students doing dance exercises, it was stated that doing exercises positively affected problem solving ability $[16,1,3]$.

In the research, it was determined that male orienteering athletes used evaluating approach sub-dmension more than female orienteering athletes. It was found by İnce $\&$ Şen (2006) that problem solving ability perception of female athletes was more positive while Karabulut \& Pulur (2011); Kuru \& Karabulut (2009) as well as Heppner \& Peterson (1982) indicated that male athletes had more positive problem solving ability perception $[14,16,18,12]$. Different from the finding of the study, Karabulut \& Ulucan (2011), Özdenk (2011), Genç (2010), Özen \& Çelebi (2006) together with Pehlivan \& Konukman (2004) stated that gender factor was not significant in problem solving [17,23,10,24,25]. The difference between studies was considered to be resulted from personal characteristics of individuals.

In the study, it was observed that married athletes had more positive problem solving ability perception than single athletes and they used effective problem solving approaches more. Pehlivan \& Konukman (2004) expressed that married physical education teachers had more positive problem solving abilities [25]. Different from this finding of the study, Efe et al. (2008) determined in their study related with football referees that marital status did not affect problem solving [8].

According to the results of the research, as the athletes get older, their problem solving abilities increase and they exhibit more thoughtful approach. Özdenk (2011) obtained results in parallel to the results of this study [23]. He stated that as the age increases, thinking and evaluating approach sub-dimensions were more frequently used. However, in the studies of Akbulut (2012) with amateur and professional male football players [4], Pulur et al. (2010) together with İnce \& Şen (2006) with basketball players [27,14], Kuru \& Karabulut (2009) on students getting rhythm education and dance lecture [18], it was stated that age was not effective on problem solving.

As the years of experience in orienteering sports increased, it was observed that problem solving ability perception of athletes was more positive. It was indicated by Efe et al. (2008) that as seniority of football referees increased, their problem solving ability perception also increased [8]. Pehlivan \& Öksüzoğlu (2006) expressed that problem solving ability was directly proportional to the experience of the individual [26]. Different from the 
result of this study, a significant difference was not found between problem solving abilities of football players and their sports experience by Gülşen (2008) [11].

In the research, it was found that displaying performance at the level of being national affected problem solving ability perception positively. In the studies of Kuru \& Karabulut (2009) together with Karabulut et al. (2009) [18,15], different from this study, a significant difference was not found between being a national athlete and problem solving.

The results of the research indicated that gender, marital status, age, experience and being national of orienteering athletes affected problem solving ability perception. As the age and experience of orienteering athletes are improved, problem solving ability perception is positively developed. It is considered that doing sports at national level increases the number of experiences and positively affects self-confidence and approaches towards problems sportsmen. For this reason, it is necessary for sportsmen to face with different problems in training and race tracks arranged with many different techniques and the trainers should present opportunities to them in order to find the most appropriate solution.

\section{References}

1. Acar, K. Futbol eğitimi alana çocuklarda problem çözme becerileri ve fonksiyonel olmayan tutumların incelenmesi, Doktora Tezi, Selçuk Üniversitesi, Sağlık Bilimleri Enstitüsü, Konya, Türkiye. (2013).

2. Adair, J. E. Decision making and problem solving strategies. Kogan Page Publishers. (2007)

3. Akandere, M, Baştuğ, G, Demir H. \& Taşğın, Ö. Examining problem solving skills of the students practising dance for 12 weeks in terms of gender variable. Ovidius University Annals, Series Physical Education and Sport Science, Movement and Healty; 2: 635-638(2010).

4. Akbulut, A. K. Amatör ve profesyonel erkek futbolcuların karar verme, problem çözme ve iletişism becerilerinin bazı değişkenler bakımından incelenmesi, Doktora Tezi, Gazi Üniversitesi, Eğitim Bilimleri Enstitüsü, Ankara, Türkiye. (2012).

5. Çağlayan, H.S., Taşğın, Ö. \& Yıldız, Ö. Spor yapan lise öğrencilerinin problem çözme becerilerinin çeşitli değişkenler açısından incelenmesi. Niğde Üniversitesi Beden Eğitimi ve Spor Bilimleri Dergisi, 2(1):62-77. (2008).

6. Deniz, E., Karaman, G., Bektas, F., Yoncalik, O., Güler, V., Kılınç, A. \& Ateş, A. Çocuklarda oryantiring eğitimi, Kültür Ajans Yayınları, Ankara. (2012).

7. Dictionary of sport and exercise science:[over 5000 terms clearly defined]. A \& C Black Publishers Ltd., London. (2006).

8 Efe, M., Öztürk, F. \& Koparan, Ş. Bursa ilindeki faal futbol hakemlerinin problem çözme ve atılganlık düzeylerinin belirlenmesi. Spormetre Beden Eğitimi ve Spor Bilimleri Dergisi, 6(2), 49-58 (2008).

9. Erden, M., \& Akman, Y. Eğitim psikolojisi: Gelişim-öğrenme-öğretme. Arkadaş Yayınevi, Ankara. (1996).

10. Genç, S. Z. Öğretmen adaylarının empatik becerileri ile problem çözme becerileri. Kuramsal Eğitimbilim Dergisi, 3(2), 135-147 (2010).

11. Gülșen, D. Farklı lig düzeyinde oynayan futbolcuların oynadıkları mevkilere, öğrenim durumu ve spor yaşlarına göre problem çözme becerilerinin incelenmesi. Yüksek Lisans Tezi, Çukurova Üniversitesi, Sağlık Bilimleri Enstitüsü, Adana, Türkiye. (2008).

12. Heppner P. P. \& Petersen, C. H. The Development and Implications of a Personal Problem Solving Inventory. Journal of Counseling Psychology. 29(1), 66-75. (1982). 
13. Heppner, P. P. \& Krauskopf, C. J. An information-processing approach to personal problem solving. The Counseling Psychologist, 15(3), 371-447 (1987).

14. İnce, G. \& Şen, C. Adana ilinde deplasmanlı ligde basketbol oynayan sporcuların problem çözme becerilerinin belirlenmesi. Spormetre Beden Eğitimi ve Spor Bilimleri Dergisi, 4(1), 5-10. (2006).

15. Karabulut, E .O., Kuru, E. \& Pulur, A. Beden eğitimi öğretmenliği bölümü öğrencilerinin problem çözme becerilerinin çeşitli değişkenler açısından incelenmesi (Ahi Evran ve Gazi Üniversiteleri Örneği). Niğde Üniversitesi Beden Eğitimi ve Spor Bilimleri Dergisi, 3(3), 272-279. (2009).

16. Karabulut, E. O. \& Pulur, A. Gençlik merkezlerine üye gençlerin temsilcilerinin problem çözme becerilerinin çeşitli değişkenler açısından karşılaştırılması. Spormetre Beden Eğitimi ve Spor Bilimleri Dergisi, 9(2), 71-80. (2011).

17. Karabulut, E. O. \& Ulucan, H. Yetiştirme yurdunda kalan öğrencilerin problem çözme becerilerinin çeşitli değişkenler bakımından incelenmesi (Kırşehir ili örneği). Ahi Evran Üniversitesi Eğitim Fakültesi Dergisi, 12(1), 227-238. (2011).

18. Kuru, E. \& Karabulut, E. O. Ritim eğitimi ve dans dersi alan ve almayan beden eğitimi ve spor yüksekokulu öğrencilerinin problem çözme becerilerinin çeşitli değişkenler bakımından incelenmesi. Gazi Eğitim Fakültesi Dergisi, 29(2), 441-458 (2009).

19. Mayer, R. E. Thinking, problem solving, cognition. (2nd ed). New York: W. H. Freeman and Company. (1992).

20. Morgan, CT., Psikolojiye Giriş Ders Kitabı. Çev. Arıcı, H. Ankara: Hacettepe Üniversitesi Psikoloji Bölümü Yayınlan, No: 1.7,23, (1981).

21. Nezu, A. M. \& D' Zurilla, T. J. Solving life's problems: a5 step guide to enhanced wellbeing, NewYork. Springer Publishing Company: 4. (2007).

22. Oxford Dictionary of English 2e Oxford University Press. (2003),

23. Özdenk, S. Düzenli egzersizin Fırat Üniversitesi beden eğitimi ve spor yüksekokulu öğrencilerinin problem çözme becerileri üzerine etkisi. Yüksek Lisans Tezi, Fırat Üniversitesi, Sağlık Bilimleri enstitüsü, Elazığ, Türkiye. . (2011).

24. Özen, G. \& Çelebi, M. Dağcılık eğitimi alan kişilerin farklı değişkenler açısından problem çözme becerilerinin incelenmesi, 9. Uluslararası Spor Bilimleri Kongresi ( 35 Kasım), Muğla, 957-959. (2006).

25. Pehlivan, Z., \& Konukman, F. Beden eğitimi öğretmenleri ile diğer branş öğretmenlerinin problem çözme becerisi açısından karşılaştırılması. Spormetre Beden Eğitimi ve Spor Bilimleri Dergisi, 2(2), 55-60. (2004).

26. Pehlivan, Z., \& Öksüzoğlu, P. Futbol ve dansla uğraşan üniversite öğrencilerinin problem çözme becerileri. 9. Uluslararası Spor Bilimleri Kongresi (3-5 Kasım), Muğla, 633-637. (2006).

27. Pulur, A., Karabulut, E. O., \& Uzun, A. Investigaton of problem solving skills in 13-15 years old male basketball players in terms of several variables. Ovidius University Annals, Physical Education And Sport/Science, Movement And Health Series, 10(2 Suppl.), 406-414. (2010).

28. Senemoğlu, N. Gelişim, Öğrenme ve Öğretim: Kuramdan Uygulamaya. Gazi Kitabevi. Ankara. (2005).

29. Şahin N., Şahin N. H. \& Heppner P. P. Psychometric properties of the problem solving inventory in a group of Turkish university8. students, Cognative Therapy and Research, 17(4), 379-396. (1993). 